\title{
Clan Culture as Predictor of Strategy Implementation: Empirical Evidence from Professional Bodies in Kenya
}

\author{
Anne W. Njagi, Joseph Ngugi Kamau, Charity Muraguri
}

\begin{abstract}
The study aimed at establishing clan culture effect as an agent of strategy implementation in professional bodies in Kenya. The study's anchoring theory was Cameroon and Queen's Competing Value Framework (CFV) supported by McKinsey 7S Framework. Positivist philosophy adopting descriptive correlation research design was implemented in the field. Key question was, "How does clan culture affect strategy implementation within the professional bodies registered with the Association of Professional Societies in East Africa within Kenya?" A census of all professional bodies with purposive proportionate sample of key respondents was undertaken. This sample involved managers of key departments involved in strategy implementation including Information Communication Technology (ICT), planning, human resources, procurement, marketing, and finance. From target sample of 168 respondents from 28 professional bodies, the study received 132 filled structured questionnaires for analysis. Multiple linear regression analysis was applied through SPSS computer package using regression models to test the hypothesis $\mathrm{H}_{01}$ : There is no relationship between clan culture and strategy implementation in professional bodies in Kenya. Findings indicated that, the coefficient for organization glue, $(\beta=.153, t=1.848, p<.05)$ and strategic emphasis $(\beta=$ $.299, t=3.609, p<.05)$ which were the constructs for clan culture significantly predicted strategy implementation in professional bodies. Results led to rejection of the null hypothesis. Study findings are significant and implementable within various organizations including government, industry players, and academia amongst others. From the findings, the study recommends leadership and policy planners to implement clan culture as demonstrated by the most successful organizations.
\end{abstract}

Index Terms - Clan Culture, Organization Glue, Professional Bodies, Strategic Emphasis, Strategy Implementation.

\section{INTRODUCTION}

Organizational culture as explained by [2] is a complicated topic with researchers disagreeing on its definition, usage, and interpretation. The majority view culture as something that an organization follows daily to execute its activities. Optimists argue that culture is a tangible resource that can be customized to enhance organization performance. Al-Ali et al. [2] argue that how one views culture has a direct influence regardless of one's beliefs that it can be modified. Culture depends on many separate factors that each, in turn, influences the other. The

Published on July 23, 2020

Anne W. Njagi, Chandaria Business School, USIU, Kenya.

(corresponding e-mail: waringanjagi @ yahoo.com)

Joseph Ngugi Kamau, Chandaria Business School, USIU, Kenya.

Charity Muraguri, Chandaria Business School, USIU, Kenya. scholars further state that some of these factors are controllable while others are not.

Strategy implementation entails the decisions about linking strategy, structure, motivational systems, and resources to achieve organizational goals [29]. It describes the process through which strategies and policies are brought into action through programs and procedures. The process of operationalizing plans entails daily decisionmaking particularly for resource allocation [6]. Strategy implementation is also the point at which the execution of strategic management takes place. It includes aspects of making decisions about linking strategy, structure, systems, and resources [9].

Pakdil and Leonard [33] noted that an assessment of the organizational culture is part of the strategic planning process. The authors also proposed that a high level of organizational culture conformity led to a more efficient implementation of strategy as opposed to a robust organizational culture alone. Elsewhere, [38] established that when it comes to strategy implementation, adequate actions taken by the management are more significant than their capabilities. As a result, the strategic awareness that reveals itself through task allocation and decision-making power is more critical than the managers' knowledge and supplementary skills.

Empiric research on the relationship between the general strategy of an entity and culture was conducted in Turkey. Tasgit, Şentürk, and Ergün [39] hypothesized that culture and strategy within an organization are equally conditioned. They did not make assumptions on the inter-relation of organizational culture and strategy but had an interest in operationalizing mutual conditions relationship by indicating a high correlation in place when culture and strategy implementation are compared. Therefore, for businesses to implement strategy, it is essential to build a specific organizational culture.

Successful strategic implementation is linked to organizational culture [40]. Therefore, organizations should develop cultural values by promoting commitments in implementing business strategy. Conversely, top management cannot achieve strategy implementation alone since it requires teamwork [35]. Strategy implementation requires originality and understanding of the organization as well as evaluating the firm's strengths. On the other hand, [41] suggests that organizations should flexibly amend organizational structure in keeping with changes in the competitive environment.

Dayan, Heisig, and Matos [18] emphasized that implementing strategy is operations-oriented and is aimed at the performance of core business activities that must be carried out strategically. De Mooij [19] opines that a 
company can only achieve a competitive edge through its strategy and only at a point where execution is done in a skillful method. Poor implementation of strategy has in the past been blamed on various strategic failures most of which are mentioned as lack of commitment by top management [22]. Strategy management has witnessed a positive trend in organizations particularly in the 21 st Century [32]. The topic of strategy implementation continues to attract scholars particularly in developing countries since the literature on the same is scarce [6].

\section{Statement OF THE PROBlem}

According to a report published by the PricewaterhouseCoopers (PWC), only a few firms may close the gap between their strategy and strategy execution successfully and only organizations that have capacity and value proposition might bridge the strategy execution gap [8]. Moreover, [3] claims that a firm can only achieve a competitive advantage through its ability to proactively execute and scan the environment. Businesses therefore must ascertain that the development and execution of strategy have an objective process [25]. Anderson [3] further noted that thinking strategically is increasingly becoming important for modern enterprises while De Mooij [190] hypothesizes that effective implementation of a strategy that is strong and robust aids in a firm achieving a significant competitive edge.

Several studies conducted worldwide have examined the association between organizational culture and strategy implementation. Naranjo-Valencia, Jiménez-Jiménez, and Sanz-Valle [31] explored the question of the link between strategy implementation and organizational culture by focusing on the Iranian banking sector. They also analyzed the typological and dimensional correlations existing when organizational culture is rated against strategy implementation. Naranjo et al. [31] found out that adaptable cultures have more to do with the formulation of strategy and factors structural in implementation. Further, the authors found out that a significant relationship existed between strategic emphasis, culture and strategy implementation. The scholars also recommended that managers should take cognizance of all elements of culture within their organizations for successful strategy implementation.

Chen, Huang, Liu, and Zhou [14] investigated the association between organizational cultures with the successful implementation of innovative strategy among 183 Chinese organizations. The study revealed that topperforming organizations had innovative strategies that were aligned with their culture. The more the corporate strategy fitted with their culture, the more successful they were in the implementation of the strategy, in terms of speed and quality.

Wei, Samiee, and Lee [42] assert that corporate culture and corporate strategy must talk to each other. The scholars conducted a study in China and applied survey design to assess the impact of organic organizational cultures, product strategy on firm performance, and market responsiveness. According to the study, clan culture is an organic type of culture that enhances the ability to achieve a higher level of success in product development and change implementation.
The study found that the development of clan culture is always aligned with the interests of the stakeholders in companies that are constantly experiencing pressures that require a change in business processes. Further, the study revealed that clan culture increases the cohesion force between the members of an organization and helps in implementing strategies because every member of the organization is inclined towards embracing the changes.

These cited studies clearly show the power of organizational culture in influencing corporate strategy implementation and therefore a firm should ensure that its strategy is aligned with their culture for effective implementation. These studies thus created an inspiration to carry out more research to establish the relationship between organizational culture and strategy implementation focusing on clan culture within professional bodies registered with Association Professional Societies in East Africa (APSEA), Kenya.

\section{LITERATURE REVIEW}

This study was based on the Competing Values Framework (CVF) by [11]. The assessment of organizational culture is based on the Organizational Culture Assessment Instrument (OCAI) developed by Cameron and Quinn. They postulated that every organization has four competing values where they exist in a blended fashion. The tool makes it possible to determine which culture types are present in an organization. Their position was that organizations do not have a single culture but have a dominant culture. Putra, Syah, Pusaka, and Indradewa [34] support this view by stating that the competing values framework shows that organizational cultures compete against each other.

Cameron and Quinn [11] noted that flexible organizations are the most successful because they can change from one culture to another based on trends. There are four effectiveness criteria models in the CVF, also referred to as four organizational culture quadrants. Based on past studies on organizational culture, Cameron and Quinn [11] characterized the four culture types as market, hierarchy, adhocracy, and clan. In the four quadrants, the four organizational types are located.

Flexibility, discretion, and dynamism

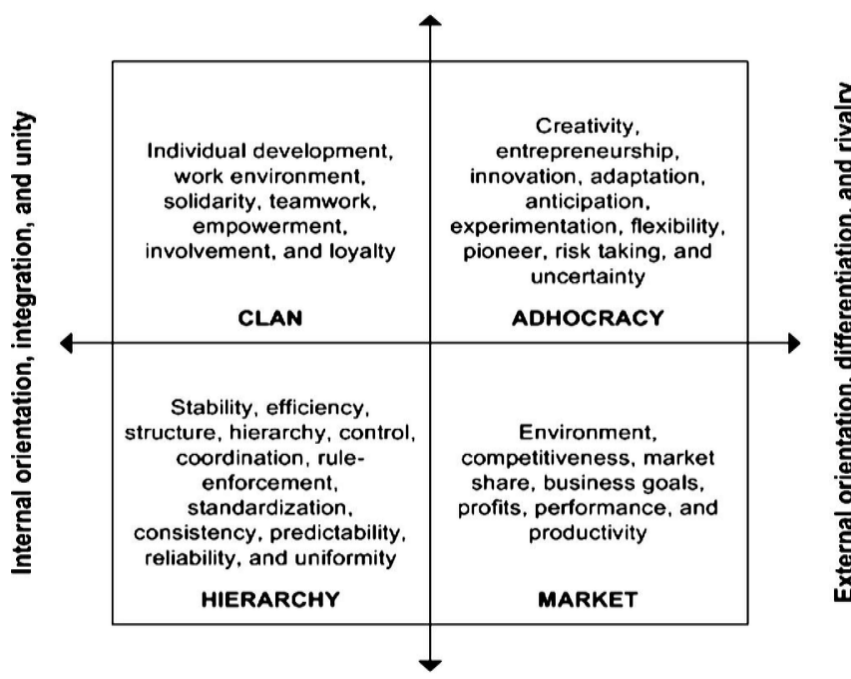

Stability, order, and contro

Fig. 1. The four dimensions of Cameron and Quinn Model. 


\section{A. Clan Culture}

A clan culture resembles a family-like type of corporate setting that dwells on coaching, supporting, and performing duties and roles together like a family [1]. It emphasizes more on commonality and consensus of goals and values. Where there is clan culture, the working environment is very friendly and employees have much in common just like a family. This is comparable to an extended family.

Clan culture is the most synergetic type of culture. It is the most uncompetitive among the four dimensions of organizational culture and is characterized by trust, teamwork, and support. Leaders of the organization at various levels are seen as father figures or mentors. On the other hand, Al-Ali et al. [2] state that the main responsibility of clan culture is to facilitate mentorship of those under a leader's jurisdiction and show commitment to involve employees in the organization's activities. This would then promote loyalty and empower employees to increase productivity and promote business success.

Organizations that adopt clan culture care about the development of their employees and their involvement in daily activities more than following rules and regulations as in hierarchies [33]. Great value is attached to staff relationship with an inward focus for integration and staff participation is encouraged. Chatterjee, Pereira, and Bates [13] posit that to ensure a coherent working environment and teamwork, employees are rewarded for their high performance as a team rather than as individuals.

The origin of the advancement of clan culture came to the limelight after studies done in the 1960s and 1970s investigated why Japanese firms were successful [11]. Researchers observed remarkable differences between the American corporations where the market and hierarchy design were dominant while the Japanese firm had a teamcentered approach reminiscent of clan form design. The Japanese firm seemed more like an extended family rather than economic entities, as they had a lot of cohesion, employee involvement, commitment, and a sense of "weness" [14]). Something distinguishing that was observed is that in Japanese firms, semi-autonomous work teams could hire and fire their members and got rewards based on team accomplishment. There were also quality domains that inspired their members to voice their suggestions on ways of improving their performance and how things can be done in the company [12].

Later Western and American organizations developed this culture because they believed that clan culture could facilitate an organization to adapt to a changing environment due to the glue holding them together such as shared goals, values, and beliefs [14]. The American firms that adopted clan culture in the late 1970s and 1980s realized that it made good business sense. For instance, they realized that during turbulent times in the marketplace when planning was difficult and decision making uncertain coordination of business activities was effective where an organization had a clan culture.

Coccia [15] refers to People Express Airlines as an example of an organization in the United States that adopted clan culture. The founder, Don Burr, introduced the clan culture that resulted in the instant success of the company within two years against experts' expectations and predictions. Some of the notable characteristics of People Express that led to its success were minimal management levels, self-management, and informality as well as employee ownership. Others included the presence of a selfselected work team of three to four people, the participation of not less than four unconnected management committees to help the firm make decisions and job rotation where sometimes pilots were involved in handling baggage and in reservations hosts. Coccia concluded that the downfall of People Express occurred when the company was merged with Frontier Airlines due to the incompatibility of clan culture with the highly unionized airline.

Davis and Cates [17] pinpoint that the basic assumption of clan culture is that people can behave appropriately when there is trust in each other, loyalty to the company and when there is a mentorship through employee engagement Customers are assumed partners of the organization. Some of the espoused values of clan culture are attachment, affiliation, trust, collaboration, and support, while the artifacts or behaviors are teamwork, employee involvement, participation, and open communication. It is further assumed that since clan culture promotes human affiliation, employees develop favorable attitudes that are oriented towards the company.

However, critics of clan culture argue that companies adopting this form of culture lack diversity. [20] highlight the persistence of the clan-oriented culture arguing that its deep-seated roots interfere with organizational structures. The proposition of clan culture by Cameron and Quinn is relevant to this study. Clan culture facilitates a 'we' feeling, sense of belonging, and teamwork. If the organization has formulated new strategies, it would be easier to implement them in such a friendly and family-like environment. This culture creates trust and motivation among staff members.

Clan culture is appropriate for an organization intending to apply the transformational approach because the culture facilitates a platform for the human assets and the leaders to collaborate in implementing strategies. This type of culture is engaging and quite intriguing for the employees because they have the freedom to propose ideas that help in the attainment of mutual benefits within the organization [13].

Gerami [21] carried out a study on the relationships between culture dimensions and strategy implementation based on Iranian nuclear policy. The study established that organizational culture and strategy implementation were significantly associated. Gerami also established that to some extent the varying clan culture influenced the strategy implementation process but less the hierarchy culture. [27] conducted a survey on Software Process Improvement (SPI) within certified Taiwanese organizations to establish the organizational culture's influence on the strategy. Findings indicated that companies that relied on a hierarchy-based organizational culture were likely to face challenges implementing the SPI strategy because of the negative implications on innovation. The bureaucratic environment was seen to hinder creativity among the human assets and organizational cultures that foster power distances among members in different levels of the organization resulting in poor strategy implementation. The study recommended the application of the clan culture as a desirable approach towards enhancing the ability to implement strategies in the 
organization. A clan culture eliminates the negative influence of power while improving collaborative work among the employees; thus, enhancing the potential of applying the SPI strategy.

Arditi, Nayak, and Damci [5] surveyed to establish the impact of delays in construction associated with time and cost overruns in construction companies in the USA and India because of organizational culture. Delays were only experienced in some companies. Findings indicated that the performance of the human resources in some of the companies was the main issue that led to a delay in implementation. Findings also linked the low performance to certain types of organizational cultures. The development of large projects in construction requires leaders and managers to foster the development of an organizational culture that is linked to the teamwork. According to this study, one of the most viable type of culture is clan, which is associated with the team playing and the development of high cohesiveness. These factors influence high performance and commitment to achieving set goals within the timelines. A considerable relationship between culture and the timely delivery of goals in the construction industry exists; hence, the implementation of a strategy is easier when clan culture is applied by companies in the construction industry [5].

\section{B. Organization Glue}

The social adhesive holding together the clan culture environment is what is called organization glue [2]. By so doing, organization glue enables the various links in the organization to remain socially attached through a commitment to set goals and accomplishment of the same goals. Social glue enables workers to put aside their differences and focus specifically on what strategically brings them together from the top personnel to the very lowest cadre. Further explanation puts it that the strategy to use what for what and why, gives an organization that social glue that drives it forward in uniformity. Social glue ensures that the result is as envisaged in the strategic plan at the beginning with both planners and stakeholders owning the document [14].

Goal accomplishment calls for a united front in facing the daily as well as the strategic requirements of the organization [25]. However, each individual might try to view their accomplishments in their manner. To avoid these, there has to be set measurements or standards that can determine what and when it should be applied [17]. The measures and standards set by the organization then have to be standardized across various management as well as operational levels to enable their accomplishment. A system of alerting winnings and losses then becomes necessary to have both encouragement and deterrent messages for the two groups. As a continuation to the next generation, once such organization social glue starts entrenching in the organization, there is a need to have documentation that can enable monitoring of the glue trend. Once a culture is assimilated into people, the tendency to remain there is always high, and this calls for good leaders that can help sustain it [29].

\section{Strategic Emphasis}

In the simplest terms, strategic emphasis points towards what is expected of an organization from the beginning to the long-term journey of development [22]. Specifically, the strategic emphasis of an organization brings out the firm's direction and what exactly is to be achieved for the long term benefits of not just the organization but stakeholders as well [32]. From the definition of strategic emphasis, it becomes clear that human development cannot escape the attention of planners in the strategic environment. This would require a competitive approach to developing the human resource function to ensure only the best of the best in the job market is retained objectively and competitively.

Strategic emphasis brings out exactly how an organization plans to move ahead and what it stands for in terms of the definition of core projects [22]. The strategic emphasis gives a way forward and the nature of every other project or mission assignment that the organization has embarked on By giving prominence to strategic emphasis, an organization draws in the stakeholders and focuses on the direction of their goal. The organization investors are also drawn to the strategic emphasis as it gives them a hint of how their funds are strategically directed [34]. The aim and purpose of the organization over the long term are therefore printed in the minds of all those involved as a means of walking together on the long journey of strategy implementation. The focus of strategic emphasis calls for new resources that would be key in the accomplishment of organization strategy. Even without new resources, existing ones require revamping or redirecting towards current goals and objectives [41].

\section{Strategy Implementation}

A dependent variable, according to [36] is one whose outcome is predictable by other variables. Similarly, [16] describe the dependent variable as the predicted, monitored, measured, and one that is estimated using all other variables. This study had strategy implementation as the dependent variable.

\section{E. Policy Formulation}

Dayan et al. [18] argue that policy formulation plays an important role in bringing together the organization's stakeholders involved in strategy implementation. Without proper policy formulation, it becomes difficult to win over any doubting staff members especially in management when making strategic decisions.

\section{F. Policy Implementation}

According to [7], the effective implementation of an ordinary strategy can beat the additional rate execution of an exceptional strategy. The scholars further argue that organizations do not fail at the point of developing strategies but at the point of execution of the strategic plans such that they not only spend long hours but also have meager resources in the form of human resources, technical and financial resources.

\section{G. Resource Allocation}

Baroto et al. [7] add that adequate allocation of time and its management is a resource allocation issue that could be facilitated by organizational culture. Clan culture (homely working environment), may have diverse and specific 
influence and varied levels of magnitude of influence on strategy implementation.

\section{H. Motivation}

Coccia [15] concludes that motivation plays an important role in the evolution of any organization in terms of both development and behavioral change that can be attributed to the success of that organization. This also plays a critical role in the personality development of staff in an organization where every person would like to feel appreciated and liked for their actions towards the success of that organization.

\section{Methodology}

Saunders, Lewis, and Thornhill [37] describe positivism in terms of philosophical stance for the scientist concerning gathering information about a phenomenon to identify associations and generalize. This view is also shared by [24] who adds that positivism mainly depends upon the field measurable data with a chance of being statistically explored. This study adopted a positivist approach, involving a hypothesis based on the theoretical framework in testing the hypothesis. The philosophy as applied in the study was dictated by observations and descriptions in the field without any influence of the phenomenon as supported by [28]. As pointed out by [30], the study eliminated any possible subjectivism and ensured all activities were objective while collecting data.

This study applied a descriptive correlation research design to establish clan culture and its relationship with strategy implementation in professional bodies in Kenya. Hermida and Young [23] indicated that descriptive correlation aims at exploring the existence of various associations amongst the variables of a phenomenon. A correlation research design, which is descriptive, was used to establish the changes in the dependent variable.

The target population for this study was all the 28 professional bodies in Kenya, registered with APSEA. The sample comprised of 168 managers from human resource, finance, marketing, planning, ICT, and procurement departments were purposively selected from each of the 28 institutions. The key instrument used was a selfadministered questionnaire using the drop and pick method to access respondents. The response rate was $79 \%$. Regression analysis was used in testing the null hypothesis through ANOVA.

\section{FINDINGS}

Regression analysis was done to establish the extent to which clan culture (independent variable) affects strategy implementation in professional bodies in Kenya. Having passed the regression assumption tests of linearity, multicollinearity and homoscedasticity tests, linear regression was used to test the hypothesis that: -

H01: There is no relationship between clan culture and strategy implementation in professional bodies in Kenya.

The model summary results presented in Table 1 indicate that clan culture significantly affects strategy implementation $(p<.05)$. Further, clan culture explained
$10.3 \%$ of strategy implementation in professional bodies in Kenya $(\mathrm{R} 2)=.103$ while the remaining $89.7 \%$ are explained by other factors not captured in this study.

TABle 1: Model Summary of Clan Culture AND STRATEGy IMPLEMENTATION

\begin{tabular}{|c|c|c|c|c|c|c|c|c|c|}
\hline \multirow[b]{2}{*}{ Model } & \multirow[b]{2}{*}{$\mathrm{R}$} & \multirow{2}{*}{$\begin{array}{c}\mathrm{R} \\
\text { Square }\end{array}$} & \multirow{2}{*}{\multicolumn{2}{|c|}{$\begin{array}{l}\text { Adjusted Std. Error } \\
\text { R of the } \\
\text { e Square Estimate }\end{array}$}} & \multicolumn{5}{|c|}{ Change Statistics } \\
\hline & & & & & $\begin{array}{c}\text { R } \\
\text { Square } \\
\text { Change }\end{array}$ & $\begin{array}{c}\mathrm{F} \\
\text { Change }\end{array}$ & $\mathrm{df}^{1}$ & $\mathrm{df}^{2}$ & $\begin{array}{c}\text { Sig. F } \\
\text { Change }\end{array}$ \\
\hline 1 & $.342^{\mathrm{a}}$ & .117 & .103 & .55227 & .117 & 8.534 & 2 & 129 & .000 \\
\hline
\end{tabular}

\section{A. Regression of Analysis of Variance (ANOVA)}

The regression ANOVA showed that clan culture had a significant influence on strategy implementation $\mathrm{F}(2,131)$ $=8.534, \mathrm{p}<.05)$ as indicated in Table 2 . This shows that the regression model was suitable for predicting the outcome variable on how clan culture influenced strategy implementation in professional bodies in Kenya than using other models.

TABLE 2: REgRESSION ANOVA OF CLAN CULTURE ON STRATEGY IMPLEMENTATION

\begin{tabular}{ccccccc}
\hline \multirow{2}{*}{ Model } & $\begin{array}{c}\text { Sum of } \\
\text { Squares }\end{array}$ & df & $\begin{array}{c}\text { Mean } \\
\text { Square }\end{array}$ & F & Sig. \\
\hline \multirow{4}{*}{1} & Regression & 5.206 & 2 & 2.603 & 8.534 & $.000^{\mathrm{b}}$ \\
& Residual & 39.345 & 129 & .305 & & \\
Total & 44.551 & 131 & & & \\
\hline \multicolumn{6}{c}{ a. Dependent Variable: Strategy implementation } \\
& b. Predictors: (Constant), Strategic emphasis, Organization glue
\end{tabular}

\section{B. Regression Coefficient on Clan Culture and Strategy Implementation}

In the regression coefficients model, the result showed that clan culture statistically predicted strategy implementation. For the organization glue, $(\beta=.153, t=$ $1.848, p<.05)$ and strategic emphasis $(\beta=.299, t=3.609$, $p<.05)$. This means, one unit of increase in organization glue increased the unit of strategy implementation by .153 and a unit increase of strategic emphasis increased the unit of Strategy implementation by .299 as presented on Table 3 .

TABle 3: COEFFicientS OF Clan CUlture ON STRATEGY IMPLEMENTATION

\begin{tabular}{ccccccc}
\hline \multirow{2}{*}{ Model } & \multicolumn{2}{c}{$\begin{array}{c}\text { Unstandardized } \\
\text { Coefficients }\end{array}$} & $\begin{array}{c}\text { Standardized } \\
\text { Coefficients }\end{array}$ & \multirow{2}{*}{$\mathrm{t}$} & \multirow{2}{*}{ Sig. } \\
\cline { 3 - 5 } & \multicolumn{1}{c}{$\mathrm{B}$} & \multicolumn{2}{c}{ Std. Error } & Beta & & \\
\hline \multirow{2}{*}{1} & $\begin{array}{c}\text { (Constant) } \\
\text { Organization } \\
\text { glue }\end{array}$ & 1.880 & .463 & & 4.063 & .000 \\
& $\begin{array}{c}\text { Strategic } \\
\text { emphasis }\end{array}$ & .157 & .085 & .153 & 1.848 & .047 \\
\hline
\end{tabular}

a. Dependent Variable: Strategy implementation

From the coefficient table, the values of the regression model were derived:

The general form of the regression model used was:

$$
\mathrm{Y}=\beta_{0}+\beta_{\mathrm{i}} \mathrm{X}_{\mathrm{i}}+\beta_{\mathrm{ii}} \mathrm{x}_{\mathrm{i}}+\varepsilon
$$

$\beta_{0}=$ Constant;

$\beta_{\mathrm{i}}=$ Organization glue;

$\beta_{\mathrm{ii}}=$ Strategic emphasis;

$\varepsilon=$ Error term. 
Thus, from the coefficient table, Clan Culture influenced Strategy Implementation in professional bodies in Kenya

$$
\mathrm{Y}=1.880+.153 \mathrm{X}+.299 \mathrm{X}+.087
$$

The linear regression analysis was used to test if clan culture significantly predicted strategy implementation among employees in professional bodies in Kenya. Thus, the null hypothesis $H_{01}$ : There is no relationship between clan culture and strategy implementation in professional bodies in Kenya was redetected and the alternate hypothesis: - H01: There is a significant relationship between clan culture and strategy implementation in professional bodies in Kenya accepted.

\section{DISCUSSIONS}

The study is in line with other scholars including [4] which identified a clear significant association between strategy implementation and clan culture. The scholars have demonstrated that performance in an organization is well improved when the implementation of a strategy is well rooted in the clan culture of a particular organization. Similarly, [1] have pointed out the importance of having the adoption of clan culture internally as well as externally to cope with various externalities in the business environment. The same can be said of the implementation of strategy if gaps are well filled through fostering of communication that gives incentives to all staff in organizations to feel part of the whole process from the planning stage to the implementation level. This implies that a well-implemented strategy requires an environment in which clan culture acts as the glue to the whole process.

As pointed out by [2] there can be teamwork created through clan culture, which cultivates an atmosphere of cooperation leading to successful strategy implementation. On the contrary, [5] from their study on the impact of organizational culture on construction delays indicated that the very clan culture of an organization plays a negative role in the implementation of strategy in which some organizations will always want 'status quo' to remain. This makes it very difficult to implement the strategy as some members of an organization always prefer the business as usual way of doing things. Arditi et al. point to the many delays that occur during the implementation phase as being caused by the clan culture adopted in an organization.

This contradicting view on clan culture can also be seen in studies by [13] in their study on the effect of the personal opinion of organizational culture on the learning transfer environment, which disputes the hypothesis that culture plays a positive role in strategy implementation entirely. The scholars argue that only a few straits in a given culture are positive and do not dominate the implementation of the strategy. The scholars contend that apart from a few, many straits in a culture impede effective strategy implementation. Given that scholars have differing views on the positive effects of clan culture on strategy implementation, it is clear that the difference in the strategy implementation success is dependent on the nature of culture in the organization.

Clan culture comes across as development of togetherness in which any leader should implement at the workplace. The traditions of family upbringing in most societies present the first occasions in which clan culture comes into play. Employees feel at home when treated in a clan culture environment and this has been proven to have positive effects on the implementation of plans. Small organizations in particular have strong linkages amongst staff, which makes it easier to adopt clan culture.

In summary, the regression output showed clan culture had a significant influence on strategy implementation. Organization glue, $(\beta=.153, \mathrm{t}=1.848, \mathrm{p}<.05)$ and strategic emphasis $(\beta=.299, \mathrm{t}=3.609, \mathrm{p}<.05)$. The study thus rejected the null hypothesis and concluded that there is a significant relationship between clan culture and strategy implementation in professional bodies in Kenya.

\section{CONCLUSION AND POLICY IMPLICATION}

Following the study results and conclusion, further studies, perhaps using a different context and scope to strengthen the findings that clan culture, indeed, is a strong factor in strategy implementation are recommended. The study results could also be used by amongst others, policymakers in both professional bodies and the government to give directions on strategy implementation. The study recommends adaptation of clan culture and research on other regions to identify if various cultures from different people have a relationship in the influencing of strategy implementation. Similarly, various organization setups could have different clan culture and that could be another point of investigation for future studies.

\section{REFERENCES}

[1] Abubakar, A. M., Elrehail, H., Alatailat, M. A., \& Elçi, A. (2019) Knowledge Management, Decision-Making Style, and Organizational Performance. Journal of Innovation and Knowledge, 4(2), 104-114. https://doi.org/10.1016/j.jik.2017.07.003

[2] Al-Ali, A. A., Singh, S. K., Al-Nahyan, M., \& Sohal, A. S. (2017). Change Management through Leadership: The Mediating Role of Organizational Culture. International Journal of Organizational Analysis, 25(4), 723-739.

[3] Anderson, J. (June 2015). Signpost for the Future: Sustaining Competitive Advantage through Major Change. In G. Williams, J. Suglia, A. Dickinson, \& T. Reijns, Frontiers in Finance| Driving Competitive Advantage through A New Investment Banking Culture (Pp. 2-3). Amstelveen, Netherlands: PMG International Cooperative ("KPMG International").

[4] Bagher Arayesh, M., Golmohammadi, E., Nekooeezadeh, M., \& Mansouri, A. (2017). The Effects of Organizational Culture on the Development of Strategic Thinking at the Organizational Level International Journal of Organizational Leadership, 6(2), 261-275.

[5] Arditi, D., Nayak, S., \& Damci, A. (2017). Effect of Organizational Culture on Delay in Construction. International Journal of Project Management, 35(2), 136-147.

[6] Awino, Z. B., Njeru, W. G., \& Adwet, K. (2017). Strategy Implementation: Mckinsey's 7s Framework Configuration and Performance of Large Supermarkets in Nairobi, Kenya. Archives of Business Research, 5(6).

[7] Baroto, M. B., Arvand, N., \& Ahmad, F. S. (2014). Effective Strategy Implementation. Journal of Advanced Management Science, 2(1), 50 54.

[8] Boegman, H. (2016). Africa Business Report, Seeing the Glass HalfFull. PWC Africa Business Agenda. Https://Www.Pwc.Co.Za/En/Assets/Pdf/Africa-Business-Agenda2016.Pdf. Accessed 4 June 2020.

[9] Burgelman, R. A. (2020). Strategy Is Destiny: How Strategy Making Shapes A Company's Future. Free Press.

[10] Cameron, K. \& R. E. Quinn. (2006). Diagnosing And Changing Organizational Culture: Based On The Competing Values Framework. Beijing: China Renmin University Press. 
[11] Cameron, K. S., \& Quinn, R. E. (1999). Diagnosing and Changing Organizational Culture. Upper Saddle River, NJ: Prentice Hall.

[12] Cameron, K., \& Ettington, D. (1999). The Conceptual Foundations of Organizational Culture. In J. Smart, Higher Education: Handbook Of Theory And Research (Pp. 356-396). New York: Agathon.

[13] Chatterjee, A., Pereira, A., \& Bates, R. (2018). Impact of Individual Perception of Organizational Culture on the Learning Transfer Environment. International Journal of Training and Development, 22(1), 15-33.

[14] Chen, Z., Huang, S., Liu, C., Min, M., \& Zhou, L. (2018). Fit Between Organizational Culture And Innovation Strategy: Implications For Innovation Performance. Sustainability, 10(10).

[15] Coccia, M. (2018). Motivation and Theory of Self-Determination: Some Management Implications in Organizations. Journal of Economics Bibliography, 5(4), 223-230.

[16] Cooper, D. R., \& Schindler, P. S. (2014). Business Research Methods (12th Ed.). New York: McGraw Hill.

[17] Davis, R., \& Cates, S. (2018). The Implementation of Organizational Culture Assessment Instrument in Creating a Successful Organizational Culture Change. International Journal of Business and Public Administration, 15(1), 71-94.

[18] Dayan, R., Heisig, P., \& Matos, F. (2017). Knowledge Management as a Factor for the Formulation and Implementation of Organization Strategy. Journal of Knowledge Management, 21(2), 308-329.

[19] De Mooij, M. (2018). Global Marketing and Advertising: Understanding Cultural Paradoxes. SAGE Publications Limited.

[20] Fotaki, M., \& Jingjit, R. (2018). Humanising Bureaucracy: ClanOriented Culture in the Thai Civil Service. In Public Policy in the 'Asian Century' (pp. 151-183). Palgrave Macmillan, London.

[21] Gerami, N. (2018). Iran's Strategic Culture: Implications for Nuclear Policy. In Crossing Nuclear Thresholds (Pp. 61-108). Palgrave Macmillan, Cham.

[22] Greer, C. R., Lusch, R. F., \& Hitt, M. A. (2017). A Service Perspective for Human Capital Resources: A Critical Base for Strategy Implementation. Academy Of Management Perspectives, 31(2), 137-158.

[23] Hermida, A., \& Young, M. L. (2017). Finding the Data Unicorn: A Hierarchy of Hybridity in Data and Computational Journalism. Digital Journalism, 5(2), 159-176.

[24] Higham, R. (2018). "To Be Is To Respond": Realizing A Dialogic Ontology For Deweyan Pragmatism. Journal of Philosophy of Education, 52(2), 345-358.

[25] Kim, J. S., \& Han, S. H. (2017). Examining The Relationship Between Civil Servant Perceptions Of Organizational Culture And Job Attitudes: In The Context Of The New Public Management Reform In South Korea. Public Organization Review, 17(1), 157-75.

[26] Knights, D., \& Willmott, H. C. (1987). Organizational Culture as Management Strategy: A Critique and Illustration from the Financial Services Industry. International Studies of Management \& Organization, 17(3), 40-63.

[27] Lee, J. C., Shiue, Y. C., \& Chen, C. Y. (2016). Examining the Impacts of Organizational Culture and Top Management Support of Knowledge Sharing On the Success of Software Process Improvement. Computers in Human Behavior, 54, 462-474

[28] Lepore, L., Metallo, C., Schiavone, F., \& Landriani, L. (2018) Cultural Orientations and Information Systems Success in Public and Private Hospitals: Preliminary Evidences from Italy. BMC Health Services Research, 18(1).

[29] Lynch, S. E., \& Mors, M. L. (2019). Strategy Implementation And Organizational Change: How Formal Reorganization Affects Professional Networks. Long Range Planning, 52(2), 255-270.

[30] Marsonet, M. (2019). Philosophy and Logical Positivism. Academicus International Scientific Journal, 19, 32-36.

[31] Naranjo-Valencia, J. C., Sanz Valle, R., \& Jiménez Jiménez, D. (2010). Organizational Culture as Determinant Of Product Innovation. European Journal of Innovation Management, 13(4), 466480 .

[32] Olson, E. M., Slater, S. F., Hult, G. T. M., \& Olson, K. M. (2018) The Application of Human Resource Management Policies within the Marketing Organization: The Impact on Business and Marketing Strategy Implementation. Industrial Marketing Management, 69, 6273.

[33] Pakdil, F., \& Leonard, K. M. (2017). Implementing and Sustaining Lean Processes: The Dilemma of Societal Culture Effects. International Journal of Production Research, 55(3), 700 717.

[34] Putra, R. P., Syah, T. Y. R., Pusaka, S., \& Indradewa, R. (2019). Human Resources Implementation Using the Mckinsey's 7s Method for Business Startup: Duck Nugget Frozen Food. Journal of Multidisciplinary Academic, 3(3), 11-14.
[35] Rajasekar, J., \& Khoud, A. (2014). Factors Affecting Effective Strategy Implementation in a Service Industry: A Study of Electricity Distribution Companies in the Sultanate of Oman. International Journal of Business and Social Science, 5(9), 169-183.

[36] Reddy, M. (2017). The Effect of Organizational Culture on Strategy Execution (Doctoral Dissertation, University Of Pretoria). Http://Hdl.Handle.Net/2263/59757. Accessed 04 June 2020.

[37] Saunders, M., Lewis, P., \& Thornhill, A. (2016). Research Methods for Business Students (Seventh Ed.). Harlow: Pearson.

[38] Shaqrah, A. (2018). Analyzing Business Intelligence Systems Based On 7s Model Of Mckinsey's. International Journal of Busines Intelligence Research, 9(1), 53-63.

[39] Tasgit, Y. E., Sentürk, F. K., \& Ergün, E. (2017). Corporate Culture And Business Strategy: Which Strategies Can Be Applied More Easily In Which Culture? International Journal of Business and Social Science, 8(6), 80-91.

[40] Turlais, V., \& Dubkevics, L. (2017). Comparative Analysis of Organizational Culture Models in Management Science. Turiba University. International Scientific Conference; Riga, 204-212.

[41] Warrick, D. D. (2017). What Leaders Need To Know About Organizational Culture? Business Horizons, 60(3), 395-404.

[42] Wei, Y. S., Samiee, S., \& Lee, R. P. (2014). The Influence of Organic Organizational Cultures, Market Responsiveness, and Product Strategy on Firm Performance in an Emerging Market. Journal of the Academy of Marketing Science, 42(1), 49-70. https://doi.org/10.1007/s11747-013-0337-6. 